\title{
Surface characterization of different particles arising as a result of coal combustion process in selected power plants from Central Poland using ToF-SIMS
}

\author{
Jacek Grams, Katarzyna Bawolak \\ Technical University of Łódź, Institute of General and Ecological Chemistry, ul. Żeromskiego 116, 90-924 Łódź, Poland, \\ e-mail: jgrams@mail.p.lodz.pl
}

\begin{abstract}
The aim of this work was the ToF-SIMS investigations of different particles arising as a result of a coal combustion process in selected power plants from Central Poland. The chemical composition and distribution of particular compounds on the studied surfaces were determined. Moreover, the ratio of the quantity of aromatic and aliphatic hydrocarbons adsorbed on the surface of the particles was estimated. A qualitative analysis of the studied samples demonstrated the presence of a big number of various compounds, including heavy metals such as $\mathrm{Pb}, \mathrm{Cd}$ and As on the investigated surfaces. In the prevailing number sample components were distributed non-homogenously on the surface and the larger areas richer in a certain type of ions were observed.
\end{abstract}

Keywords: ToF-SIMS, particle, coal combustion, power plant.

Presented at VII Conference Wasteless Technologies and Waste Management in Chemical Industry and Agriculture, Międzyzdroje, 12 - 15 June, 2007.

\section{INTRODUCTION}

The coal combustion process causes a formation of various residues. The fly ash, slag, soot and dust (formed in the process of the desulfurization of combustion gas) usually contain a big number of environmentally dangerous compounds. Heavy metals and polycyclic aromatic hydrocarbons (PAHs) are common toxic substances. These pollutants are usually adsorbed on the surface of arising particles. The presence of such impurities in the air environment has a negative influence on human health. Therefore, monitoring of the composition of the surface of arisen particles is indispensable. One of the techniques, which can be used for the investigation of residues of the coal combustion process, is time-of-flight secondary ion mass spectrometry (ToF-SIMS). This technique allows measuring micro areas of various solids including the particles formed as a result of human activity $^{1-7}$. Owing to the application of the ToF-SIMS the data concerning the upper monolayer of the studied samples can be obtained. The information of both organic and inorganic compounds can be received. Besides the determination of the chemical composition of the investigated samples, also the estimation of the distribution of particular components of the studied surface is possible ${ }^{8-9}$.

In the present work the surface of fly ash, slag and dust (formed in the process of desulfurization of combustion gas) particles formed as a result of the coal combustion process in selected power plants from Central Poland will be investigated using the ToF-SIMS. The chemical composition and distribution of particular components on the studied surfaces will be determined. Moreover, the ratio of the quantity of aromatic and aliphatic hydrocarbons adsorbed on the particle surface will be estimated.

\section{EXPERIMENTAL}

The samples of fly ash, slag and dust (formed in the process of desulfurization of combustion gas) were collected from power plants localized in the region of Central Poland (details are presented in Table 1).
Table 1. Types of collected samples

\begin{tabular}{|c|c|}
\hline Emission source & Type of sample \\
\hline Power Plant - Kutno & $\begin{array}{c}\text { Fly ash collected from multicell } \\
\text { cyclone } \\
\text { Product of desulfurization process }\end{array}$ \\
\hline $\begin{array}{c}\text { Power Plant - } \\
\text { Gostynin }\end{array}$ & $\begin{array}{c}\text { Fly ash collected from multicell } \\
\text { cyclon } \\
\text { Fly ash collected from sack filters } \\
\text { Slag }\end{array}$ \\
\hline
\end{tabular}

The ToF-SIMS measurements were performed using an IONTOF GmbH instrument (TOF-SIMS IV) equipped with 25 $\mathrm{kV}$ pulsed ${ }^{69} \mathrm{Ga}^{+}$primary ion gun in the static mode (primary ion dose about $10^{13} \mathrm{ions} / \mathrm{cm}^{2}$ ). The analysed area corresponded to a square of $100 \mu \mathrm{m} \times 100 \mu \mathrm{m}$ in the case of secondary ion mass spectra collecting and surface imaging. For each sample three spectra from different surfaces areas were taken. To obtain a plain surface of the studied material (then better mass resolution could be achieved), if it was possible, powder samples were tableted before the measurements. The tablets or powder were attached to a sample holder using a double-sided tape. Because the samples were insulating, an application of charge compensation during the measurements was necessary (a pulsed electron flood gun was used). The collected mass spectra were normalized, by using the values of total counts.

The amount of carbon was measured by an automatic carbon analyzer TOC 5000 (Shimadzu) equipped with a solid sample module.

\section{RESULTS AND DISCUSSION}

The analysis of carbon content in the investigated samples showed that in the case of fly ash originated from various sources the amount of carbon generally ranges from $34.5 \%$ (multicell cyclone - the Kutno Power Plant) to $25.4 \%$ (sack filters - the Gostynin Power Plant). A considerably lower quantity of carbon was observed for the particles of the product of the desulfurization process $(1.8 \%)$. The amount of carbon in slag samples varied in the range of about $10 \%$. 
Table 2. The values of $\mathrm{C}_{6} \mathrm{H}_{5}{ }^{+} / \mathrm{C}_{3} \mathrm{H}_{5}{ }^{+}$intensity ratio

\begin{tabular}{|c|c|}
\hline Type of sample & $\begin{array}{c}\left(\mathrm{C}_{6} \mathrm{H}_{5}{ }^{+} / \mathrm{C}_{3} \mathrm{H}_{5}{ }^{+}\right) \\
{\left[10^{-2}\right]}\end{array}$ \\
\hline $\begin{array}{l}\text { Fly ash collected from multicell cyclone - } \\
\text { Power Plant - Kutno }\end{array}$ & 6,9 \\
\hline $\begin{array}{l}\text { Product of desulfurization process - Power } \\
\text { Plant - Kutno }\end{array}$ & 4,3 \\
\hline $\begin{array}{l}\text { Fly ash collected from sack filters - Power } \\
\text { Plant - Gostynin }\end{array}$ & 6,8 \\
\hline $\begin{array}{l}\text { Fly ash collected from multicell cyclone - } \\
\text { Power Plant - Gostynin }\end{array}$ & 6,0 \\
\hline Slag - Power Plant - Gostynin & 8,3 \\
\hline
\end{tabular}

It is generally known that one of the most toxic substances, which can be found on the surface of the products of coal combustion are polycyclic aromatic hydrocarbons. Therefore, the determination of the quantity of such compounds is necessary. One of the analytical techniques, which allows comparing the surface concentration of aliphatic and aromatic compounds, is the ToF-SIMS. The values of $\mathrm{C}_{6} \mathrm{H}_{5}{ }^{+} / \mathrm{C}_{3} \mathrm{H}_{5}{ }^{+}$intensity ratio (ions corresponding to the presence of aromatic and aliphatic fraction, respectively) are shown in Table 2 . The variation of such a ratio is strictly connected with the changes of the character of carbon compounds. For the fly ash samples the $\mathrm{C}_{6} \mathrm{H}_{5}{ }^{+} / \mathrm{C}_{3} \mathrm{H}_{5}{ }^{+}$ratio ranges from $6.9 \cdot 10^{-2}$ (multicell cyclone - the Kutno Power Plant) to $6.0 \cdot 10^{-2}$ (multicell cyclone - Gostynin Power Plant). An increase in the value of this ratio was observed in the case of slag $\left(8.3 \cdot 10^{-2}\right.$ - the Gostynin Power Plant). It means that carbon compounds present in the last sample have the most aromatic character. The opposite situation was observed in the case of the product of the desulfurization process of combustion gas, where the $\mathrm{C}_{6} \mathrm{H}_{5}{ }^{+}$/ $\mathrm{C}_{3} \mathrm{H}_{5}{ }^{+}$ratio remained on the level at $4.3 \cdot 10^{-2}$.

The next part of ToF-SIMS measurements was devoted to the investigations of chemical composition and distribution of particular components on the surface of the studied particles. The most interesting ions distinguished on the mass spectra obtained from fly ash, slag and the product of desulfurization process were shown in Table 3. It appeared that a qualitative composition of the studied surfaces was much the same in the case of all the investigated particles. The presence of various metals (including heavy metals such as

Table 3. Ions distinguished on the mass spectra obtained from the surface of studied particles

\begin{tabular}{|l|l|}
\hline Positive ions & Negative ions \\
\hline $\mathrm{Al}^{+}, \mathrm{Ca}^{+}, \mathrm{K}^{+}, \mathrm{Na}^{+}, \mathrm{Mg}^{+}, \mathrm{Si}^{+}$, & $\mathrm{H}^{-}, \mathrm{O}^{-}, \mathrm{OH}^{-}, \mathrm{C}^{-}, \mathrm{C}_{2}^{-}, \mathrm{CH}^{-}, \mathrm{CH}_{2}^{-}, \mathrm{C}_{2} \mathrm{H}^{-}$ \\
$\mathrm{C}^{+}, \mathrm{C}_{2} \mathrm{H}_{5}^{+}, \mathrm{C}_{3} \mathrm{H}_{5}^{+}, \mathrm{C}_{6} \mathrm{H}_{5}^{+}$, &, $\mathrm{C}_{2} \mathrm{HO}^{-}$, \\
$\mathrm{B}^{+} \mathrm{Li}^{+}, \mathrm{Ti}^{+}, \mathrm{V}^{+}, \mathrm{Cr}^{+}, \mathrm{Mn}^{+}$, & $\mathrm{CHO}_{2}^{-}, \mathrm{CN}^{-}, \mathrm{S}^{-}, \mathrm{HS}^{-}, \mathrm{SO}^{-}, \mathrm{SO}_{2}^{-}$, \\
$\mathrm{Fe}^{+}$, & $\mathrm{SO}_{3}^{-}, \mathrm{SO}_{4}^{-}$, \\
$\mathrm{Ni}^{+}, \mathrm{Co}^{+}, \mathrm{Cu}^{+}, \mathrm{Zn}^{+}, \mathrm{As}^{+}$, & $\mathrm{P}^{-}, \mathrm{PO}^{-}, \mathrm{PO}_{2}^{-}, \mathrm{PO}_{3}^{-}, \mathrm{F}^{-}, \mathrm{Cl}^{-}, \mathrm{Br}^{-}$ \\
$\mathrm{Cd}^{+}, \mathrm{Pb}^{+}$ & \\
\hline
\end{tabular}

arsenic, lead and in a few cases cadmium) and compounds containing carbon, sulphur, phosphorus and halogens atoms, were confirmed. However, the quantity of the above mentioned components can differ considerably. In order to show such differences the normalized intensities of signals originated from the most interesting ions were shown in Tables 4 and 5 .

The ToF-SIMS results obtained for the products of the combustion process in the Gostynin Power Plant revealed a higher emission of $\mathrm{Ca}^{+}, \mathrm{Ti}^{+}, \mathrm{Cr}^{+}, \mathrm{Mn}^{+}, \mathrm{Ni}^{+}, \mathrm{Co}^{+}, \mathrm{Cl}^{-}, \mathrm{PO}_{2}^{-}$ and $\mathrm{SO}_{\mathrm{x}}^{-}$ions in the case of the fly ash from sack filters in comparison with the fly ash from the multicell cyclone. The opposite situation was observed for $\mathrm{Li}^{+}$and $\mathrm{Fe}^{+}$. Moreover, the mass spectrum of the second sample exhibits a lower intensity of signals corresponding to the presence of heavy metals, such as $\mathrm{As}$ and $\mathrm{Pb}$ (the amount of $\mathrm{Cd}$ below detection limit). The analysis of the surface of slag collected from the same installation demonstrates high emission of $\mathrm{Ca}^{+}$ signal and the presence of a considerably bigger amount of As and $\mathrm{Pb}$ than in the case of fly ash samples. A big quantity of $\mathrm{Ca}$ determined on the slag surface is caused by an addition of $\mathrm{Ca}$ containing compounds during the combustion process in order to remove sulphur from the flue gas.

As it was mentioned earlier, owing to the application of the ToF-SIMS, also the information about the distribution of individual components of the investigated surface can be obtained. In the case of the fly ash taken from the multicell cyclone an arrangement of various ions on the analysed area is almost uniform (Figure 1A). However, a certain number of $\mathrm{Ca}$ and $\mathrm{Fe}$ species with the size of a few micrometers is observed. The distribution of ions on the surface of the particles originating from sack filters is non-homogenous. Among the others the presence of a bigger size of $\mathrm{Li}, \mathrm{Si}, \mathrm{K}$, $\mathrm{Ca}$ and Fe species was noticed (Figure 1B).

The comparison of the surface composition of the particles collected from the sack filters from both Power Plants revealed a lower emission intensity of the signals corresponding to the presence of light metals and As in the case of the sample originating from Gostynin. The products from the Power Plant Kutno contained a bigger amount of $\mathrm{Ca}, \mathrm{Na}$, $\mathrm{K}, \mathrm{P}, \mathrm{S}$, and $\mathrm{Cl}$. Moreover, in this case a substantially lower emission of $\mathrm{Al}^{+}$or $\mathrm{Si}^{+}$and a similar content of $\mathrm{Pb}$ were observed. The difference in the surface composition of both samples results from a different way of the particle formation. In the Kutno Power Plant sulphur oxides arising in the coal combustion are neutralised by calcium hydroxide and the main product collected in the sack filters is the material formed during the desulfurization process.

The surface images of the product of desulfurization process from the Kutno Power Plant (not shown in this work) confirmed the high content of $\mathrm{S}, \mathrm{Ca}, \mathrm{Na}$ and $\mathrm{K}$, and revealed a uniform distribution of the observed substances on the analyzed particles.

Table 4. Normalized intensities of selected negative secondary ions

\begin{tabular}{|c|c|c|c|c|c|c|c|c|c|}
\hline \multirow[b]{2}{*}{ Type of sample } & \multicolumn{9}{|c|}{ Normalized intensities of signals } \\
\hline & 范 & $\begin{array}{l}\text { + } \\
\stackrel{0}{0} \\
0\end{array}$ & $\underbrace{\sqrt[N]{0}}_{\infty}$ & $\begin{array}{l}\text { 음 } \\
\frac{1}{U}\end{array}$ & 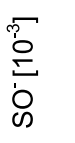 & $\begin{array}{l}+\underset{0}{0} \\
\stackrel{2}{0} \\
0 \\
0\end{array}$ & 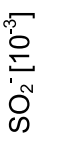 & $\begin{array}{l}\stackrel{m}{\circ} \\
\stackrel{2}{=} \\
\dot{n}\end{array}$ & 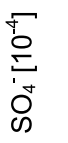 \\
\hline Fly ash collected from multicell cyclone- Power Plant - Kutno & 8.1 & 20 & 4.7 & 25 & 4.4 & 13 & 1.0 & 3.7 & 1.7 \\
\hline Product of desulfurization process- Power Plant - Kutno & 5.1 & 5.4 & 3.3 & 29 & 11 & 4.4 & 3.5 & 1.6 & 4.2 \\
\hline Fly ash collected from sack filters- Power Plant - Gostynin & 4.2 & 1.1 & 1.7 & 11 & 6.0 & 5.6 & 2.8 & 2.6 & 9.0 \\
\hline Fly ash collected from multicell cyclone- Power Plant - Gostynin & 6.9 & 2.1 & 1.2 & 7.0 & 3.9 & 1.6 & 0.6 & 1.2 & 0.6 \\
\hline Slag- Power Plant - Gostynin & 8.3 & 0.3 & 8.1 & 2.9 & 9.7 & - & 1.5 & 1.4 & 0.9 \\
\hline
\end{tabular}


Field of view. $103.0 \times 103.0 \mu m^{2}$

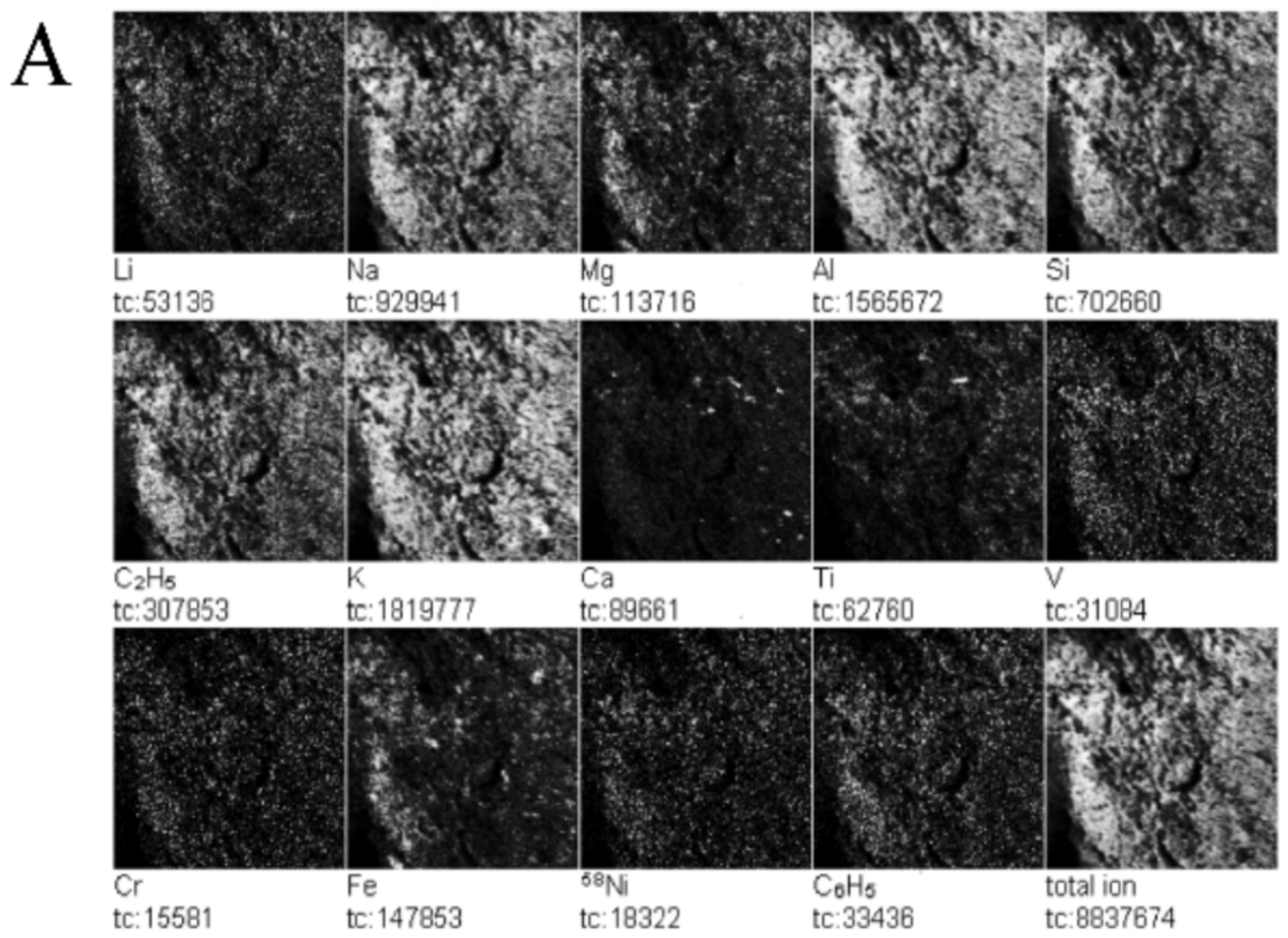

Field of view. $103.0 \times 103.0 \mu \mathrm{m}^{2}$

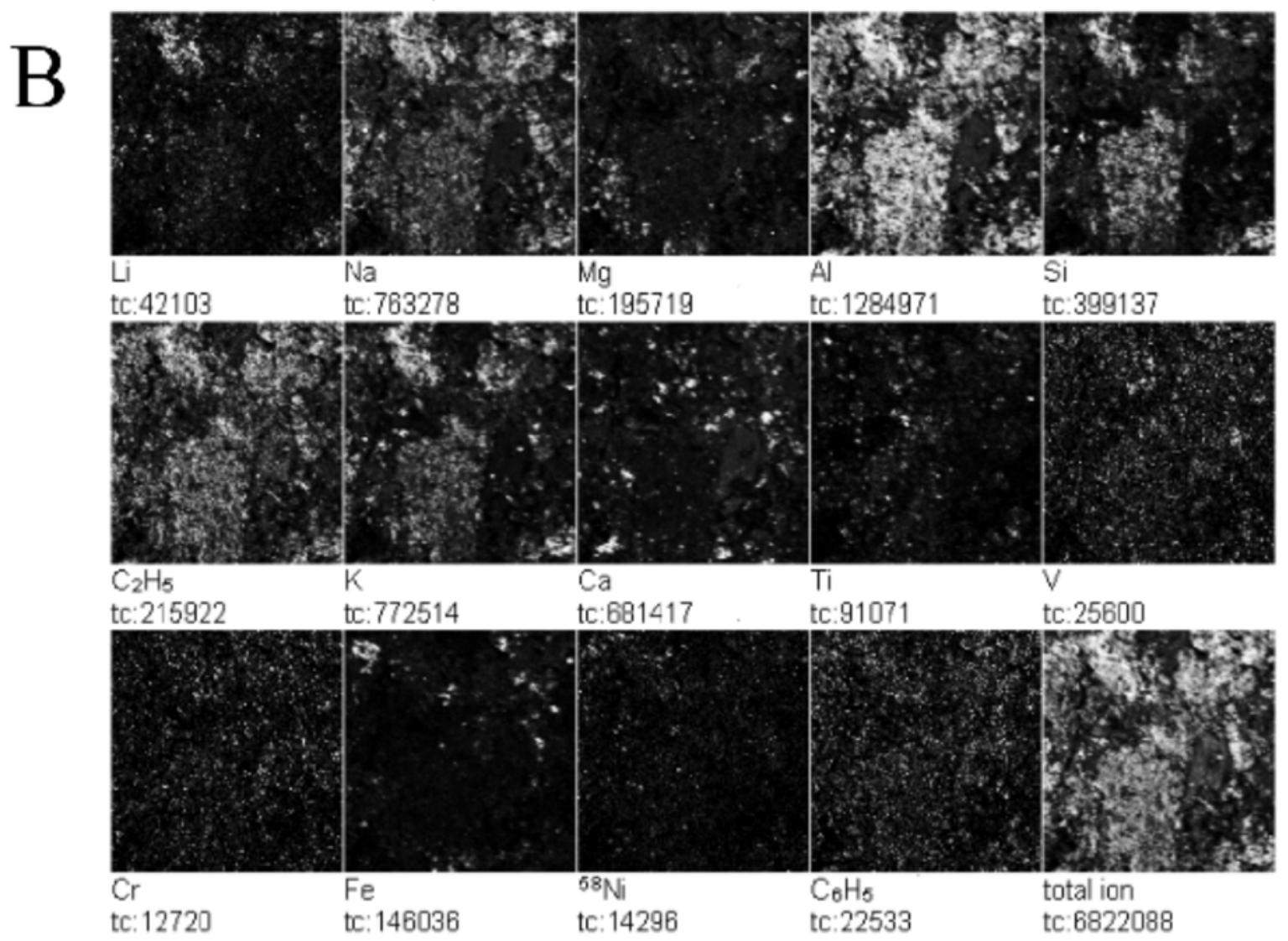

Figure 1. TOF-SIMS surface images of fly ash collected from: A - multicell cyclone and B - sack filters from Power Plant in Gostynin. Bright colour on the images indicates the presence of investigated ions 
Table 5. Normalized intensities of selected positive secondary ions

\begin{tabular}{|c|c|c|c|c|c|c|c|c|c|c|c|c|c|c|c|c|c|c|c|c|c|}
\hline \multirow[b]{2}{*}{$\begin{array}{l}\text { Type of } \\
\text { sample }\end{array}$} & \multicolumn{21}{|c|}{ Normalized intensities of signals } \\
\hline & 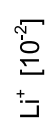 & $\begin{array}{l}+\sqrt{0} \\
0 \\
+\infty\end{array}$ & $\stackrel{+}{+\pi}$ & ${ }^{+}$ & $\stackrel{+}{\pi}$ & 漓 & \pm & (]ల & $\stackrel{+}{i}=$ & 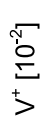 & 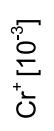 & 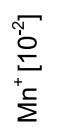 & $\begin{array}{l}+\oplus \\
\longleftarrow\end{array}$ & 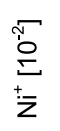 & $\begin{array}{l}\text { Tे } \\
\stackrel{0}{5} \\
0 \\
0\end{array}$ & $\begin{array}{l}\sqrt[\pi]{0} \\
\stackrel{0}{0} \\
+3 \\
0\end{array}$ & 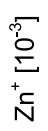 & 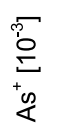 & $\begin{array}{l}+\infty \\
\text { Th } \\
0 \\
0\end{array}$ & 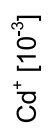 & $\begin{array}{l}\text { Tे } \\
\text { 은 } \\
+0 \\
+0\end{array}$ \\
\hline $\begin{array}{c}\text { Fly ash } \\
\text { collected from } \\
\text { multicell } \\
\text { cyclone } \\
\text { Power Plant - } \\
\text { Kutno } \\
\end{array}$ & 15 & 7.8 & 7.8 & 1.4 & 12 & 1.9 & 6.3 & 2.4 & 0.22 & 3.3 & 13 & 9.8 & 2.2 & 4.4 & 2.7 & 3.0 & 27 & 1.4 & 0.62 & - & 0.3 \\
\hline $\begin{array}{c}\text { Product of } \\
\text { desulfurization } \\
\text { process- } \\
\text { Power Plant - } \\
\text { Kutno } \\
\end{array}$ & 6.8 & 1.5 & 39 & 0.4 & 0.3 & - & 38 & 54 & 0.14 & 0.1 & 3.7 & 0.8 & 0.08 & 2.3 & 16 & 2.0 & 4.0 & 144 & 0.33 & 2.4 & 3.5 \\
\hline $\begin{array}{c}\text { Fly ash } \\
\text { collected from } \\
\text { sack filters- } \\
\text { Power Plant - } \\
\text { Gostynin } \\
\end{array}$ & 35 & 2.9 & 15 & 3.4 & 23 & 9.2 & 18 & 15 & 0.13 & 26 & 47 & 13 & 3.4 & 8.4 & 30 & 5.1 & 3.0 & 54 & 0.43 & 2.7 & 34 \\
\hline $\begin{array}{c}\text { Fly ash } \\
\text { collected from } \\
\text { multicell } \\
\text { cyclone- } \\
\text { Power Plant - } \\
\text { Gostynin } \\
\end{array}$ & 63 & 3.4 & 13 & 6.0 & 29 & 8.6 & 19 & 8.8 & 0.8 & 33 & 24 & 6.4 & 5.0 & 2.3 & 3.1 & 5.9 & - & 11 & 0.59 & - & 0.6 \\
\hline $\begin{array}{c}\text { Slag- Power } \\
\text { Plant - } \\
\text { Gostynin }\end{array}$ & 0.9 & 0.6 & 0.2 & 1.8 & 0.4 & 0.8 & 0.5 & 69 & 0.15 & 1.5 & 2.6 & 1.6 & 0.08 & 0.2 & - & 0.6 & - & 89 & 0.95 & - & 16 \\
\hline
\end{tabular}

The ToF-SIMS investigations of the surface of fly ash collected from the multicell cyclone showed that in the case of the sample from the Gostynin Power Plant the intensity of the signals originated from metals (except $\mathrm{Ni}$ and $\mathrm{Zn}$ ), was considerably higher than that observed for the material obtained from the Kutno Power Plant. On the other hand, the fly ash collected from the multicell cyclone from Power Plant Kutno contained a bigger quantity of S, P, Cl and Br.

A quantitative analysis of selected elementse made by Atomic Absorption Spectrometry (not presented in this work) generally confirmed the tendencies noticed in the ToF-SIMS measurements. Some exceptions to the rule were probably caused by the differences in the composition of the bulk and the surface of the investigated samples.

\section{SUMMARY}

The ToF-SIMS experiments allowed an estimation of the ratio of aliphatic and aromatic hydrocarbons on the surface of the investigated samples. The biggest amount of aromatic compounds was found on the surface of the slag collected from the Gostynin Power Plant. A qualitative analysis of the studied samples demonstrated the presence of a big number of various compounds, including heavy metals such as $\mathrm{Pb}$, $\mathrm{Cd}$ and As on the investigated surfaces. The analysis of the emission intensity of selected ions allowed comparing the surface composition of various samples. An application of the ToF-SIMS makes it possible to obtain valuable information about the distribution of particular substances on the surface of fly ash, slag and dust (formed in the process of the desulfurization of combustion gas) collected from the Kutno and Gostynin Power Plants. In the prevailing sample components were distributed non-homogenously on the analyzed surface and the larger areas richer in a certain type of ions were observed.

\section{ACKNOWLEDGEMENT}

We are grateful to Ms Jadwiga Albinska from the Institute of General and Ecological Chemistry, Technical University of Lodz, for her help in Atomic Absorption Spectrometry measurements.

\section{LITERATURE CITED}

(1) Ham R., Adriaens A., Prati P., Zucchiatti A., Vaeck L., Adams F.: Static secondary ion mass spectrometry as a new analytical tool for measuring atmospheric particles on insulating substrates, Atmos. Environ., 2002, 36, 899.

(2) Peterson R.E., Tyler B. J.: Analysis of organic and inorganic species on the surface of atmospheric aerosol using time-of-flight secondary ion mass spectrometry (TOFSIMS), Atmos. Environ., 2002, 36, 6041.

(3) Zheng J., Tana M., Shibatab Y., Tanakab A., Li Y., Yuanmao G., Zhang Y., Shanc Z.: Characteristics of lead isotope ratios and elemental concentrations in PM10 fraction of airborne particulate matter in Shanghai after the phaseout of leaded gasoline, Atmos. Environ., 2004, 38, 1191.

(4) Tomiyasu B., Hoshi T., Owari M., Nihei Y.: TOF-SIMS measurements for toxic air pollutants adsorbed on the surface of airborne particles, Appl. Surf. Sci., 2003, 203 - 204, 775 .

(5) Oishi S., Shirahase M., Sado M., Oiwa R.: 2003. Analysis of condensation dusts from the heavy oil combustion using TOF-SIMS, Appl. Surf. Sci., 2003, 203 - 204, 772.

(6) Wierzbicka A., Lillieblad L., Pagels J., Strand M., Gudmundsson A., Gharibi A., Swietlicki E., Sanati M., Bohgard M.: Particle emissions from district heating units operating on three commonly used biofuels, Atmos. Environ., 2005, 39, 139.

(7) Ham R., Adriaens A., Vaeck L., Adams F., TOF-SIMS, a new versatile technique for the analysis of environmental aerosols, J. Aerosol Sci., 2000, 31, 396.

(8) Hagenhoff B., High Resolution Surface Analysis by TOF-SIMS, Microchim. Acta, 2000, 132, 259-271.

(9) Vickerman J.C., Briggs D., (Eds.), TOF-SIMS Surface Analysis by Mass, IM Publications and SurfaceSpectra Limited, Chichester, 2001. 